$11-8-2017$

\title{
Who is a Nuisance? Criminal Activity Nuisance Ordinances in Ohio
}

Joseph Mead

Cleveland State University, j.mead@csuohio.edu

Megan Hatch

Cleveland State University, m.e.hatch@csuohio.edu

J. Rosie Tighe

Cleveland State University, j.I.tighe@csuohio.edu

Marissa Pappas

Kristi Andrasik

See next page for additional authors

Follow this and additional works at: https://engagedscholarship.csuohio.edu/urban_facpub

Part of the Urban Studies and Planning Commons

How does access to this work benefit you? Let us know!

\section{Repository Citation}

Mead, Joseph; Hatch, Megan; Tighe, J. Rosie; Pappas, Marissa; Andrasik, Kristi; and Bonham, Elizabeth, "Who is a Nuisance? Criminal Activity Nuisance Ordinances in Ohio" (2017). All Maxine Goodman Levin School of Urban Affairs Publications. 01231509.

https://engagedscholarship.csuohio.edu/urban_facpub/1509

This Report is brought to you for free and open access by the Maxine Goodman Levin School of Urban Affairs at EngagedScholarship@CSU. It has been accepted for inclusion in All Maxine Goodman Levin School of Urban Affairs Publications by an authorized administrator of EngagedScholarship@CSU. For more information, please contact library.es@csuohio.edu. 


\section{Authors}

Joseph Mead, Megan Hatch, J. Rosie Tighe, Marissa Pappas, Kristi Andrasik, and Elizabeth Bonham 


\title{
WHO IS A NUISANCE? \\ CRIMINAL ACTIVITY NUISANCE ORDINANCES IN OHIO
}

November 2017

\author{
By \\ Joseph Mead \\ Megan E. Hatch \\ J. Rosie Tighe \\ Marissa Pappas \\ Kristi Andrasik
}

Cleveland State University

2121 Euclid Avenue

Cleveland OH 44115

and

Elizabeth Bonham

ACLU of Ohio 


\section{SUMMARY}

Criminal Activity Nuisance Ordinances (CANOs) are local laws found throughout the country that penalize property owners if repeated incidents of criminal activity related to their property occur over a set period of time (typically, 12 months). Nearly 50 cities in Ohio have CANOs, including more than 20 in Northeast Ohio.

Drawing on extensive public records from a sample of Northeast Ohio cities, this report offers a snapshot of CANOs and how they are being used.

- CANOs disproportionately impact renters, people using housing vouchers, and people of color

- Race and class stereotypes surface in public discussions of CANOs, and are sometimes invoked to justify the establishment or enhancement of CANOs

- CANOs are frequently applied beyond their scope to target minor, non-criminal behavior

- Many cities across Ohio put survivors of domestic violence at heightened risk of eviction by defining domestic violence as a "nuisance activity"; in some cities, more than half of CANO letters are sent in response to domestic violence incidents

- If emergency services are sent to a home in response to a call made to a suicide hotline, that property can be deemed a nuisance

- Seeking medical assistance for someone experiencing a drug overdose crisis is a common reason for placing properties on a city's nuisance list

- It is often difficult or even impossible for a property owner or tenant to challenge a mistaken nuisance designation

While the findings presented in this report center on Northeast Ohio, residents in the thousands of other U.S. cities with CANOs may be experiencing similar impact. We encourage policymakers, researchers, and community stakeholders to use this report to inform deeper conversations on the implications of CANOs, and to expand research on the use and consequences of these laws.

\section{Acknowledgments}

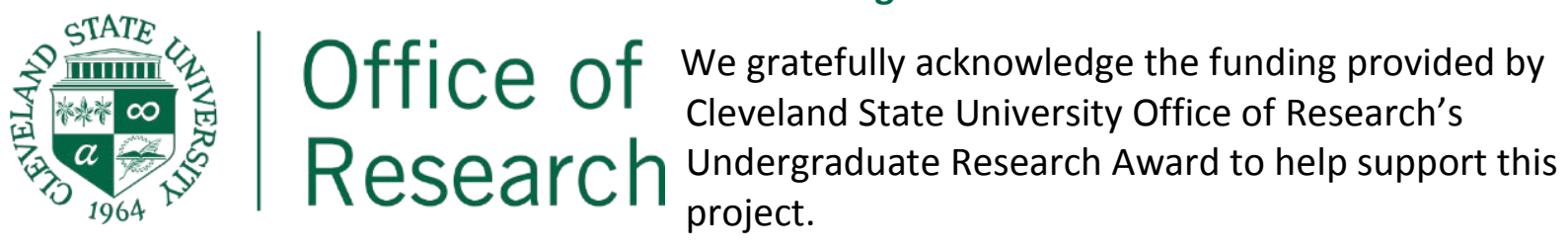

Jennifer Chandler, Mark Henning, Jacob Rivera, and Samantha Steinmetz provided superb research assistance.

We also recognize the cooperation provided by several cities in answering our public record requests. 


\section{Table of Contents}

Overview of Criminal Activity Nuisance Ordinances ...................................................... 1

PART ONE: Adopting CANOs: Motivations, Target Populations, Complications ...................... 3

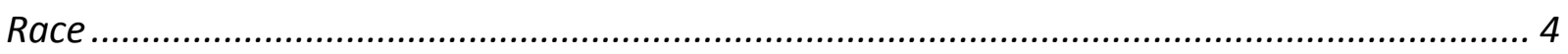

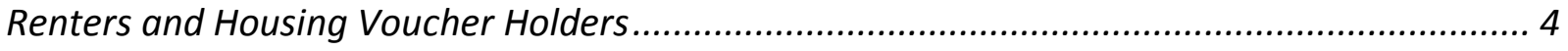

PART TWO: Implementing CANOs....................................................................... 6

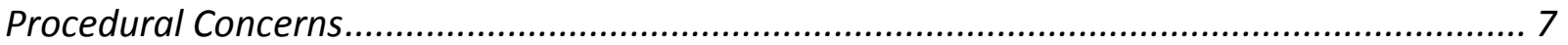

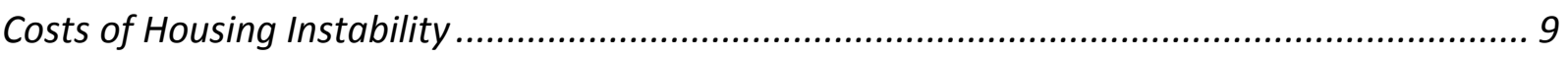

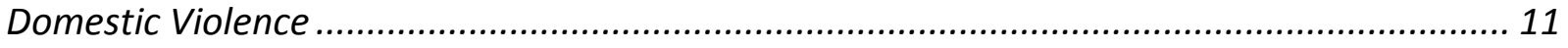

Mental Health Crises and Group Homes for People with Disabilities .................................. 14

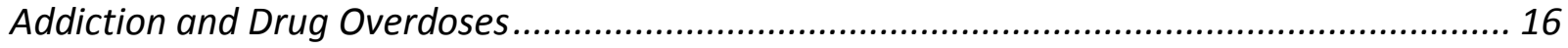

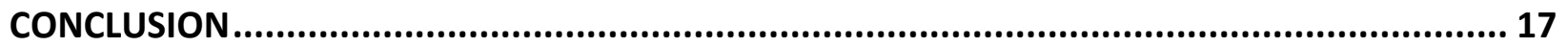

Appendix A. List of Cities and Villages in Ohio with CANOs.............................................. 19

Appendix B. Methodology .................................................................................... 21

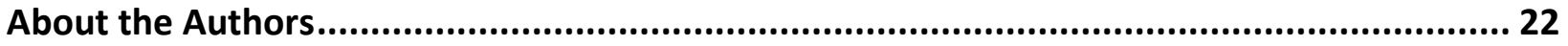




\section{Overview of Criminal Activity Nuisance Ordinances}

Criminal Activity Nuisance Ordinances (CANOs) are local laws that penalize property owners if there are repeated incidents of criminal activity on or near their property over a set period of time. Over the last 15 years, CANOs have proliferated throughout the country, ${ }^{1}$ and there are currently an estimated 2,000 such laws nationwide. ${ }^{2}$ Nearly 50 cities in Ohio have CANOs, including more than 20 in Cuyahoga County. See Appendix A for a list of these cities and Figure 1 for a map of their distribution throughout the state.

\section{Figure 1. Distribution of Cities with CANOs}

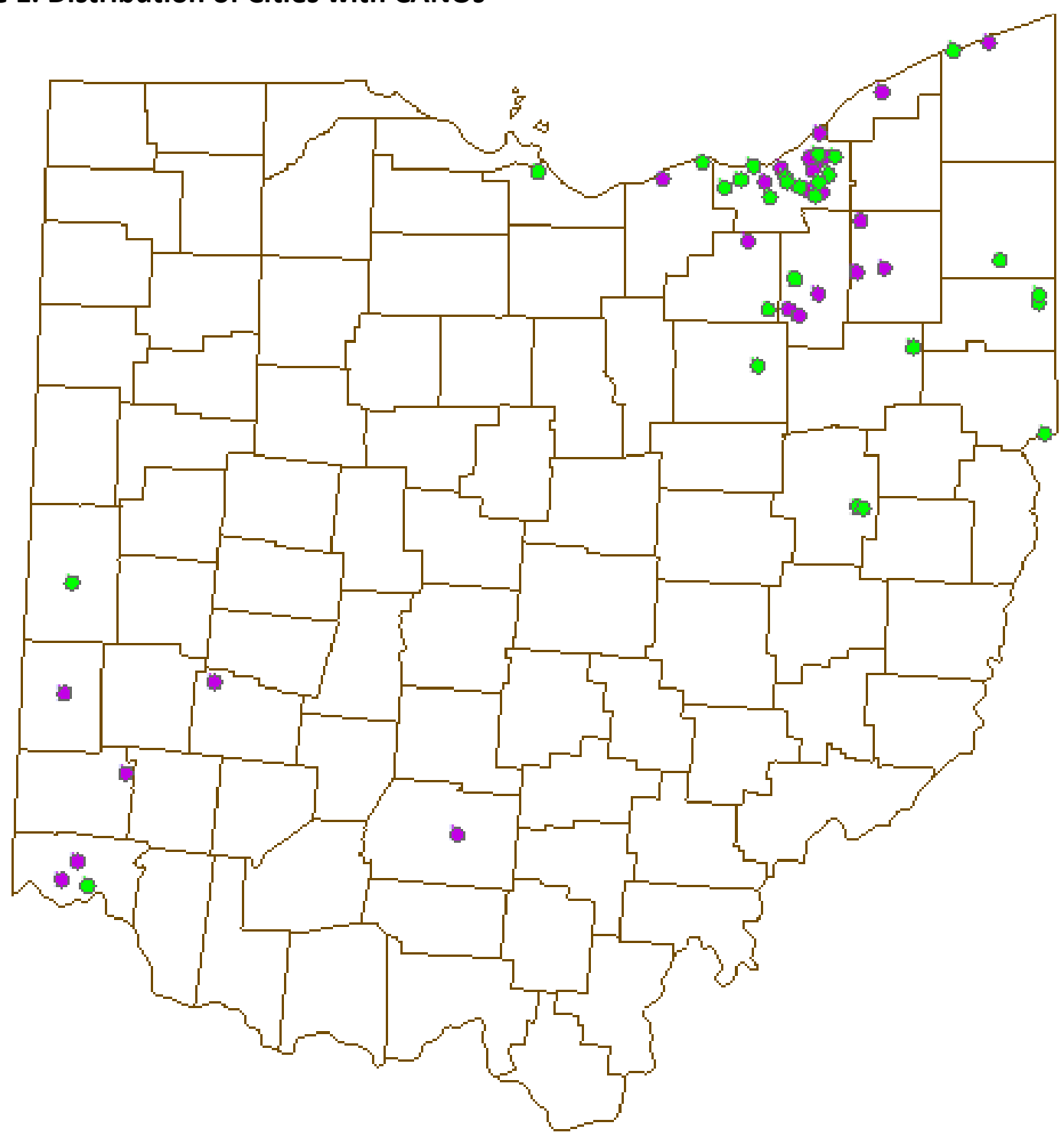

Note: Green dot = CANO with domestic violence, Purple dot = CANO without domestic violence

\footnotetext{
1 https://scholar.harvard.edu/files/mdesmond/files/unpolicing.asr2013.online.supplement 0.pdf

${ }^{2}$ Kate Walz, "Let's Stop Criminalizing Victims of Domestic Violence" (Sargent Shriver National Center on Poverty Law, 2017), https://theshriverbrief.org/lets-stop-criminalizing-victims-of-domestic-violence-a72a06b50e42.
} 
Although the specifics vary slightly city to city, CANOs tend to have similar features:

- Define nuisance: Most cities list specific offenses that qualify as a nuisance (such as drug offenses, assault, trespassing, or animal complaints), while some cities include all crimes. Some CANOs allow property owners to be penalized not only for conduct that occurs on their property, but also for conduct that occurs within a set number of feet of their property. In at least one city, a resident's conduct anywhere in the city can draw a penalty against the owner of the property where that resident lives.

- Number of nuisances in a period of time: CANOs specify the number of offenses and the relevant time period necessary to deem a property a nuisance. A typical ordinance states two or more qualifying incidents (or one, if the incident involves certain felony offenses) over a 12-month period will lead to a declaration that a property is a nuisance. $^{3}$

- Penalty: CANOs specify the penalty against the property owner if there are additional qualified incidents tied to a property after it has been declared a nuisance. A common penalty is to charge the property owner a fee for the cost of responding to an emergency call to the property. At least one city also allows a property owner to be charged with a standalone misdemeanor offense if additional qualifying incidents occur after their property was declared a nuisance. ${ }^{4}$

- Abatement: CANOs often provide that property owners can avoid being fined if they take steps to abate the nuisance at their property, typically by evicting tenants. Prior research found that landlords typically respond to a nuisance letter by pursuing formal eviction proceedings, with other landlords engaging in a self-help eviction or taking other negative action against the tenant. ${ }^{5}$

This report presents findings from a closer look at the adoption and implementation of active CANOs in Northeast Ohio. In the first part, we present findings from legislative documents to analyze cities' motivations for adopting CANOs, and the populations cities are most likely to target when adopting CANOs. In part two, we discuss the implementation of CANOs. Taking a deeper-dive into the public records and nuisance notifications of four first-ring Cleveland suburbs with active CANOs established at least 10 years ago (Bedford, Euclid, Lakewood, and Parma), we offer insight into the implications of these laws on housing stability, domestic violence, disability, mental health, and substance use issues (see Appendix B for a full explanation of study methodology).

\footnotetext{
${ }^{3}$ See, for example, Lakewood Ordinance $\S 510.01$ (c).

${ }^{4}$ Bedford Ordinance $\S 511.12$ (b) \& 511.99.

${ }^{5}$ Matthew Desmond and Nicol Valdez, "Unpolicing the Urban Poor: Consequences of Third-Party Policing for Inner-City Women," Americal Sociological Review 78, no. 1 (2012): 117-41, https://doi.org/10.1177/0003122412470829; American Civil Liberties Union, "Silenced: How Nuisance Ordinances Punish Crime Victims in New York" (New York, NY, June 2015). 


\section{PART ONE: Adopting CANOs: Motivations, Target Populations, Complications}

CANOs are often enacted in response to complaints about the behavior and activities of city residents. Documentation of the public discussions surrounding these complaints reveal tensions in these cities-residents express frustration with their neighbors' behaviors and often perceive the city and police response to their complaints to be inadequate. Common themes emerging from these tensions include discomfort with challenges to perceived community norms as new residents come into a city, and discomfort with the effectiveness of existing mechanisms to align behaviors and activities with perceived community norms (sometimes championed by city officials as "middle class values" or "community standards").

In our sample cities, CANOs appear to be an attempt to address these tensions. Our findings indicate several common motivations for adopting a CANO:

- Increase power to police department

- Serve as a formal response to resident complaints of unwelcome activities in their neighborhood

- Encode into law the regulation of resident behavior/activity according to unwritten community norms, values, or "character"

- Enlist property owners in the policing of criminal activity and the regulation of resident behavior/activity 6

Rarely do residents express concern with serious crime. Instead, residents and councilmembers complain about annoying or rude behavior and their wish for a certain community character. ${ }^{7}$ Race and class undertones are frequently evident. At times, these undertones are thinly veiled, if at all, as city officials explicitly identify populations they expect to be impacted by a CANO. Whether explicit or implicit, race and class motivations for adopting CANOs may carry serious implications for cities as courts have found that "protection of community character" can be code for racial prejudice and violates the Fair Housing Act's prohibition against race discrimination. ${ }^{8}$

\footnotetext{
6 Sarah Swan, "Home Rules," Duke Law Journal 64 (2015): 823-900; Matthew Desmond and Nicol Valdez, "Unpolicing the Urban Poor: Consequences of Third-Party Policing for Inner-City Women," American Sociological Review 78, no. 1 (February 1, 2013): 117-41, https://doi.org/10.1177/0003122412470829.

7 For example, in response to neighbor complaints about children "gathering" in a city park, the mayor was convinced that "the children needed to be sent a message," despite the police department's reminder that they "couldn't arrest anyone because the children were not causing any problems."

${ }_{8}$ Mhany Management Inc. v. County of Nassau, 819 F.3d 581 (2nd Cir. 2016); Avenue 6E Investments, LLC v. City of Yuma, Ariz., 818 F.3d 493, 506 (9th Cir. 2016); Greater New Orleans Fair Housing Action Center v. St. Bernard Parish, 641 F. Supp. 2d 563, 571 (E.D. La. 2009) ('”threat' to the 'shared values' of overwhelmingly Caucasian St. Bernard Parish clearly is an appeal to racial as well as class prejudice." (collecting cases)).
} 
Race

Racial undertones surrounding CANOs are often seen in predominantly white communities experiencing an influx of residents of color. ${ }^{9}$ For example, one city saw a rapid demographic shift over the last 15 years, moving from a majority of white residents to a majority of AfricanAmerican residents, ${ }^{10}$ while the city council and the police force remained overwhelmingly white. ${ }^{11}$ The city first adopted its CANO in 2005, where the influx of people of color was a salient concern of policymakers. At this meeting, in response to a question from a community member about "what the city is in position to do as far as addressing the mixture of the

City officials sometimes invoke race and class stereotypes when adopting CANOs community," the City Manager emphasized that other cities were also going through "these types of growing pains and experience [sic] diversity." 12 The Mayor explained:

One of the things that we take pride in is middle class values... We believe in neighborhoods not hoods.... The people who do not and bring those values out here, the values of the gang or of drugs, that will not happen here. That is one of the reasons we passed that nuisance law tonight.... [I have] made mention of the students walking down the streets and those are predominantly African American kids who bring in that mentality from the inner city where that was a gang related thing by staking their turf. We are trying to stop that. ${ }^{13}$

\section{Renters and Housing Voucher Holders}

Although CANOs as written apply to properties whether they are owner- or tenant-occupied, some cities readily identify renters as a target population when considering the adoption of a CANO. For example, one city passed its CANO with the explicit intention of fining property owners for their tenants' behavior: "if the renter is causing a problem, the landlord may also have to pay the cost to the City for excessive police calls." ${ }^{14}$ Another Councilperson concurred: "this would affect in [sic] all properties but particularly rental properties." ${ }^{15}$ In another city, the vice mayor who introduced the CANO legislation explained he hoped a nuisance notification

\footnotetext{
9 Bono, Marisa. "Don't You Be My Neighbor: Restrictive Housing Ordinances as the New Jim Crow." Mod. Am. 3 (2007): 29.

10 Census 2000, Census 2010, American Community Survey Estimate 2015.

${ }^{11}$ Nick Castele, Diversity a Challenge for Suburban Police Departments in Cuyahoga County, Ideastream (Aug. 29, 2014), http://www.ideastream.org/news/diversity-a-challenge-for-suburban-police-departments-in-cuyahoga-county

12 Bedford City Council Minutes, May 2, 2005, https://www.dropbox.com/s/fhybaot8iophvbf/BedfordMay2005.pdf?dl=0

13 Minutes Bedford May 2, 2005; see also Thomas Ott, Urban immigrants bring a culture clash to older suburbs, Plain Dealer, Jan 2, 2006 ("Cleveland's older suburbs want to stem what they see as the spread of urban ways. Bedford Mayor Dan Pocek calls it a culture clash and a quest to preserve what he and officials in other cities refer to as the suburbs' quality of life. It results from class friction in neighborhoods where the population is increasingly poor and, in many cases, black.... [Basketball hoops were taken down in Bedford after] "families were intimidated by crowds of young black males who blasted music and cursed.")

${ }^{14}$ Euclid May 5, 2006 council minutes, page 9, https://www.dropbox.com/s/z73iyfq1m39g9r4/EuclidMay52006Minutes.pdf?dl=0.

15 Ibid.
} 
would give landlords a reason to evict tenants. ${ }^{16}$ (In fact, as discussed below, renters are disproportionately targeted by CANOs.)

Some cities appear to have adopted their CANOs out of concern about properties rented to households who receive Housing Choice Vouchers. The council president in Euclid expressed repeated interest in using the CANO to target properties with renters who receive housing vouchers. The law director explained that evicting the voucher holder would be a primary means of abating nuisance, and a key benefit of the nuisance ordinance would be to empower the law department to "get [Cuyahoga Metropolitan Housing Authority] involved in that point to either [sic] suspend the person's contract." 17

\section{CANOs are passed with renters and recipients of housing subsidies in mind}

Prior research indicates fears about housing voucher holders are predominantly driven by stereotypes, often with racial undertones. ${ }^{18}$ In fact, the former name for the federal Housing Choice Voucher Program, "Section 8," is often considered to be a racial slur. ${ }^{19}$ Because protected classes (including people of color, families with children, and people with disabilities) are overrepresented among Housing Choice Voucher holders, opposition to voucher holders can often be considered unlawful discrimination. ${ }^{20}$

\footnotetext{
${ }^{16}$ Lyndhurst Council Minutes, July 6, 2009, p. 8, https://www.dropbox.com/s/5labeif3s5hqou9/Lyndhurst2009a.pdf?dl=0

${ }^{17}$ Minutes of Euclid Council Meeting, October 16, 2006, p. 15, https://www.dropbox.com/s/9qlxvu5n36hdgho/EuclidOctober\%2016\%202006\%20Council\%20Minutes.pdf?dl=0 18 J. Rosie Tighe, Megan E. Hatch, and Joseph Mead, "Source of Income Discrimination and Fair Housing Policy," Journal of Planning Literature 32, no. 1 (February 1, 2017): 3-15, https://doi.org/10.1177/0885412216670603; J. Rosie Tighe, "Public Opinion and Affordable Housing: A Review of the Literature," Journal of Planning Literature 25, no. 1 (August 1, 2010): 3-17, https://doi.org/10.1177/0885412210379974; J. Rosie Tighe, "How Race and Class Stereotyping Shapes Attitudes Toward Affordable Housing," Housing Studies 27, no. 7 (October 1, 2012): 962-83, https://doi.org/10.1080/02673037.2012.725831; Kristi Andrasik, "When It Comes to Housing, Your Voucher Is Your Stigma," Real Clear Policy, 2016, http://www.realclearpolicy.com/blog/2016/10/04/when_it_comes_to_housing_your_voucher_is_your_stigma_1724.html. 19 Emily Badger, How Section 8 became a 'Racial Slur,' Washington Post June 15, 2015, https://www.washingtonpost.com/news/wonk/wp/2015/06/15/how-section-8-became-a-racialslur/?utm term $=.46 \mathrm{dd} 1 \mathrm{f7b} 856 \mathrm{f}$

20 Paula Beck, "Fighting Section 8 Discrimination: The Fair Housing Act's New Frontier," Harvard Civil Rights-Civil Liberties Law Review 31 (1996): 155-86; Evan Forrest Anderson, "Vouching for Landlords: Withdrawing from the Section 8 Housing Choice Voucher Program and Resulting Disparate Impact Claims-- Graoch Associates \#33, L.P. v. Louisville/Jefferson County Metro Human Relations Commission, 508 F.3D 366 (6th Cir. 2007)," University of Cincinnati Law Review 78 (2009): 8; Rebecca Tracy Rotem, "Using Disparate Impact Analysis in Fair Housing Act Claims: Landlord Withdrawal from the Section 8 Voucher Program," Fordham Law Review 78 (2010): 8. United States v. City of Parma, Ohio, 494 F.Supp. 1049, 1071 (N.D.Ohio, 1980).
} 


\section{PART TWO: Implementing CANOs}

After the specified number of qualifying offenses occur on (or near) a property in a city with a CANO, the city will typically declare the property a nuisance and send a letter to the property owner alerting them to the possibility of penalty should there be subsequent offenses. Despite their name, criminal activity nuisance ordinances are used to penalize behavior even when the police would be unable to sustain formal criminal charges (due to lack of evidence), or when the behavior is not in fact criminal (as with the vague notions of "disrespect"). This ability to give the city additional tools to go after behavior without being constrained by usual levels of proof and process are heralded as key advantages of CANOs. ${ }^{21}$

Although criminal activity nuisance notifications are formally directed at property owners, it is most often renters who suffer the consequences of the notification. ${ }^{22}$ Existing research suggests the most common response for a landlord receiving a nuisance letter is to evict their tenants. ${ }^{23}$ Some cities explicitly recommend landlords evict their tenants as a way of abating a nuisance. In Euclid, many notifications include the statement: "I strongly suggest you take immediate steps...to file an eviction action to remove the tenant." ${ }^{24}$ The city's Assistant Law Director explained her approach: "I advise the homeowner that after they receive my notice, if they take the steps to abate the nuisance themselves, which may include evicting the tenant, taking care of the problem, we won't charge them." ${ }^{25}$ Even if the city does not explicitly recommend a landlord evict their tenant, nuisance notifications have been rescinded when the landlord provided evidence the tenant was evicted. ${ }^{26}$

As seen in figure 2 , most properties considered to be a nuisance are rentals.

Some cities use CANOs to prompt evictions by crosschecking any alleged criminal or disrespectful activity against lists of renters using housing

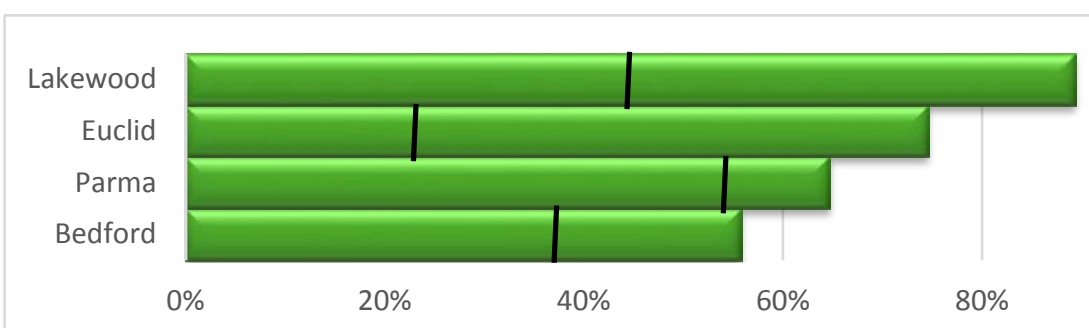
$100 \%$

Figure 2. Percentage of CANO letters that relate to rental properties (green graph) compared to percent rentals in city (black line) (2010 Census) vouchers, and then ask Cuyahoga Metropolitan Housing Authority (CMHA) to revoke vouchers for those tenants. ${ }^{27}$ In Lakewood, city council explicitly discussed cross-checking nuisance

\footnotetext{
${ }^{21}$ Lakewood Minutes, 12/15/2008, https://www.dropbox.com/s/shv4zgdhb7jpnhc/Lakewood\%20minutes\%202008.pdf?dl=0

22 American Civil Liberties Union, "Silenced: How Nuisance Ordinances Punish Crime Victims in New York."

https://www.aclu.org/files/field document/equ15-report-nuisanceord-rel3.pdf

${ }^{23}$ American Civil Liberties Union, "Silenced: How Nuisance Ordinances Punish Crime Victims in New York." https://www.aclu.org/files/field_document/equ15-report-nuisanceord-rel3.pdf; Desmond and Valdez, "Unpolicing the Urban Poor: Consequences of Third-Party Policing for Inner-City Women."

24 https://www.dropbox.com/s/9k91m0xwl3hgwt9/W.pdf?dl=0

${ }^{25}$ Euclid October 16, 2006, page 13,

https://www.dropbox.com/s/9qlxvu5n36hdgho/EuclidOctober\%2016\%202006\%20Council\%20Minutes. pdf?dl=0 26 https://www.dropbox.com/s/rdxncwagdyh8q66/Y.pdf?dl=0

${ }^{27}$ Euclid City Council minutes, October 16, 2006; Kavanaugh \& Ott, 2007, "The 'burbs clamp down: Laws directed at untoward activity, Tuesday, May 01, 2007 Cleveland Plain Dealer.
} 
violations with subsidized housing residents, indicating, "we were successful in taking one to CMHA-and one was kicked off the program." ${ }^{28}$

\section{Procedural Concerns}

The vast majority of formal eviction proceedings-whether justified or not-are uncontested, likely due to tenants' confusion about their legal rights and a lack of legal representation. ${ }^{29}$ Some cities structured their CANOs to exclude tenants from contesting the nuisance allegations against them. While discussing his city's CANO, the city manager requested an amendment, "to have the verbiage cleaned up so the warning letters, billings and/or any assessments would be mailed directly to the property owner." ${ }^{30}$ At the city manager's urging, the city further amended its law to disallow tenants from participating in the appeal process, ensuring the person likely to bear the brunt of the nuisance letter is given neither the notice nor the chance to argue against the charges. ${ }^{31}$ Other cities' CANOs specifically state the property owner has the right to appeal a nuisance notification, but does not mention the tenant's rights. ${ }^{32}$ However, some cities that allow notifications to be sent to the tenant do allow the tenant to appeal. ${ }^{33}$

A tenant's inability to appeal is particularly problematic if there is no proof the activity occurred, or if the activity is neither criminal nor actually covered by the city's ordinance. For example, despite the police reporting "all quiet on arrival," the mere unverified complaint by a neighbor about loud noise was enough to prompt one city to issue a nuisance designation. ${ }^{34}$

This may cause procedural concerns as the person facing the consequences-the tenant-does not have legal recourse to challenge the nuisance notification and is therefore treated as guilty without a right

The person accused of the nuisance activity-the tenant-is often not allowed to challenge the notification to defend themselves, even if the activity that triggered the notification did not lead to criminal charges. Some groups have therefore

\footnotetext{
28 Minutes of the Lakewood Public Safety Committee Meeting October 10, 2008, https://www.dropbox.com/s/shv4zgdhb7jpnhc/Lakewood\%20minutes\%202008.pdf?dl=0

${ }^{29}$ Matthew Desmond, Evicted: Poverty and Profit in the American City (Crown/Archetype, 2016); Matthew Desmond and Carl Gershenson, "Who Gets Evicted? Assessing Individual, Neighborhood, and Network Factors," Social Science Research 62 (February 2017): 362-77, https://doi.org/10.1016/j.ssresearch.2016.08.017.

30 Bedford City Council, Minutes of Work Session, September 5, 2017,

https://www.dropbox.com/s/sn9v3070nz1yp5f/Bedford2017minutes.pdf?dl=0.

31 Bedford Ord. No. No. 9523-17, https://www.dropbox.com/s/x61hkeprf961ilc/Ord\%209523-17.pdf?dl=0; Bedford City Council, Minutes of Work Session, September 5, 2017,

https://www.dropbox.com/s/sn9v3070nz1yp5f/Bedford2017minutes.pdf?dl=0.

32 Bedford Ord. § 511.12(b)(2), Lakewood Ord. § 509.14(e), Lyndhurst Ord § 161.04, North Olmstead Ord. § 561.02(e), Parma

Ord. §606.31(d)

${ }^{33}$ Garfield Heights Ord. § 555.04.

34 https://www.dropbox.com/s/gj72rc8t56376vj/N.pdf?dl=0
} 
raised due process concerns, ${ }^{35}$ and some courts have struck down CANOs on this ground. ${ }^{36}$ In one rather dramatic gesture, the President of the Alliance City Council refused to sign the nuisance ordinance adopted by the council, writing instead: "I respectfully must decline to sign Ord. 21-15 on the ground that it violates the Constitution." ${ }^{37}$ The City Council enacted the ordinance over the objection.

The lack of process also opens the door to targeting members of protected classes in response to generic complaints such as being "disrespectful" or youth playing basketball. We also see evidence that cities penalize juveniles, in many cases youth of color, with nuisance citations for minor transgressions, such as:

- A city fined a landlord $\$ 250$ because a 16 -year-old black resident was seen "walking through the lot of the skateboard park and pool" after curfew. ${ }^{38}$

- One nuisance letter was sent after police "spoke with a black male about shouting vulgar/profane language." 39

- One city's nuisance letter warned, "In reviewing a history of police calls connected to your property, it appears that numerous youths congregating at the home behave in a manner that is in violation of community standards," citing non-criminal behavior like "Use of profane language, annoyance to passing motorists" and "verbal confrontation" with a police officer." 40

- Under its CANO, Lakewood took aggressive city action to address neighbor complaints about an "aggressive pack of teens," "terrorizing punks" who "transgressed the norms of civility," and playing basketball in the street. Eviction proceedings followed. ${ }^{41}$

- A 2015 Euclid nuisance letter was sent complaining about “juveniles playing basketball in the street." 42

\footnotetext{
35 Watson v. Maplewood, MO, 4:17-cv-01268 (ACLU lawsuit alleges due process challenge to similar CANO); Salim Katach, "A Tenant's Procedural Due Process Right in Chronic Nuisance Ordinance Jurisdictions," Hofstra Law Review 43 (2015): 875-908; Theresa Langley, "Living Without Protection: Nuisance Property Laws Unduly Burden Innocent Tenants and Entrench Divisions between Impoverished Communities and Law Enforcement," Houston Law Review 52 (2015): 1255-86.

36 Victor Valley Family Resource Center v. City of Hesperia, 2016 WL 3647340, at *5 (C.D. Cal. 2016); Peters v. Wilkes-Barre, Case No. 3:15-cv-00152 (M.D. Pa. Jan 27 2016)

${ }^{37}$ Alliance Ord. 21-15, https://www.dropbox.com/s/a339vnxuvj7h5nz/Alliance21-15writeon.pdf?dl=0

38 https://www.dropbox.com/s/xh71y5icc25sivf/Q.pdf?dl=0

39 https://www.dropbox.com/s/k5g7yr2iwzqjlzb/P.pdf?dl=0

${ }^{40}$ https://www.dropbox.com/s/9672nx2mzb0ynhu/qq.pdf? dl=0

${ }^{41}$ Warren, 2008. "Beach Avenue Investments: Lakewood Says “No" to Bad Neighbors. Lakewood Observer 06/04/08 retrieved 8/162017 from http://lakewoodobserver.com/read/06/04/08/beach-avenue-investments-lakewood-says-no

42 https://www.dropbox.com/s/e83ykeuhbm446w5/X.pdf?dl=0
} 
- Many nuisance letters are sent in response to arguments between family members or live-in partners that do not break any laws. For example, police were called because a resident was upset at her 17-year-old son for "being disrespectful," which triggered the city to send a nuisance warning. ${ }^{43}$

\section{Cities use CANOs to target non- criminal behavior like kids playing basketball or being "disrespectful"}

Prior research in other states with similarlyworded CANOs found that CANOs were in fact disproportionately used against people of color, leading to civil rights lawsuits challenging these laws. ${ }^{44}$ Moreover, by treating CANOs as allencompassing tools to penalize trivial behavior deemed problematic-including non-criminal incidents that are not covered by the actual text of the CANO-cities raise constitutional objections for failing to provide sufficient notice of what is against the rules, affording officials too much discretion, and allowing for arbitrary (and, often, race-based) enforcement. ${ }^{45}$ Finally, by treating disrespectful, profane, or rude comments as a basis for penalizing landowners, cities could violate basic First Amendment principles. ${ }^{46}$

\section{Costs of Housing Instability}

Since eviction is the most common response to receiving a nuisance notification, these laws put residents at significant risk for housing instability. Housing instability may actually exacerbate nuisance-triggering conditions such as domestic violence, mental health crises, or drug addiction:

- Survivors of domestic violence may not seek help if they fear it will lead to housing instability or homelessness. ${ }^{47}$

- Housing instability is linked to mental health problems and even suicide. ${ }^{48}$

- Individuals who are homeless or facing housing instability are more likely than those in stable housing situations to report alcohol or drug dependency. ${ }^{49}$

\footnotetext{
43 https://www.dropbox.com/s/8kbxamdh43kxn1d/T.pdf?dl=0

44 http://povertylaw.org/files/advocacy/housing/PeoriaSuit/PeoriaNuisanceMap.pdf

http://www.stltoday.com/news/local/crime-and-courts/suit-maplewood-targets-african-americans-women-disabled-withnuisance-ordinance/article d2309e7c-8822-57ea-90a5-cf3d8098b45f.html

45 E.g., City of Chicago v. Morales, 527 U.S. 41 (1999).

${ }^{46}$ E.g., Cohen v. California, 403 U.S. 15 (1971).

47 Michelle Fugate et al., "Barriers to Domestic Violence Help Seeking: Implications for Intervention," Violence Against Women 11, no. 3 (March 1, 2005): 290-310, https://doi.org/10.1177/1077801204271959.

48 Robert M. Bossarte et al., "Housing Instability and Mental Distress among US Veterans," American Journal of Public Health 103, no. Suppl 2 (December 2013): S213-16, https://doi.org/10.2105/AJPH.2013.301277; S. F. Suglia, C. S. Duarte, and M. T. Sandel, "Housing Quality, Housing Instability, and Maternal Mental Health.," Journal of Urban Health : Bulletin of the New York Academy of Medicine 88, no. 6 (December 2011): 1105-16, https://doi.org/10.1007/s11524-011-9587-0.

${ }^{49}$ Ryan D. Murphy, Sarah E. Zemore, and Nina Mulia, "Housing Instability and Alcohol Problems during the 2007-2009 US Recession: The Moderating Role of Perceived Family Support," Journal of Urban Health : Bulletin of the New York Academy of Medicine 91, no. 1 (February 2014): 17-32, https://doi.org/10.1007/s11524-013-9813-z.
} 
In addition, housing instability and forced moves have a myriad of negative impacts on individuals, families, and neighborhoods. This is particularly acute for evicted renters, who, against their preferences, often subsequently move to a smaller

Eviction and other forced moves harm health, the ability to keep one's job, and school performance or lower quality unit ${ }^{50}$ in higher poverty and crime neighborhoods. ${ }^{51}$ Besides the immediate financial hardship, ${ }^{52}$ eviction and other forced moves negatively impact mental and physical health, ${ }^{53}$ the ability to keep one's job, ${ }^{54}$ and child academic achievement. ${ }^{55}$ These negative financial and health consequences are still observed two years after eviction. ${ }^{56}$ Neighborhoods with high mobility rates are less stable than neighborhoods with lower mobility rates, which is associated with less civic engagement and trust among community members, ${ }^{57}$ crime and gang activity, ${ }^{58}$ environmental stress, ${ }^{59}$ negative health outcomes such as stress and depression, ${ }^{60}$ and lower levels of neighborhood attachment and satisfaction. ${ }^{61}$

Evictions and forced moves have both short- and long-term consequences for the families experiencing the moves, their children, and the neighborhoods they leave. The decision to designate a property as a nuisance has potentially far-reaching consequences beyond the intention to abate the nuisance.

\footnotetext{
50 Matthew Desmond, Carl Gershenson, and Barbara Kiviat, "Forced Relocation and Residential Instability among Urban Renters," Social Service Review 89, no. 2 (June 1, 2015): 227-62, https://doi.org/10.1086/681091.

51 Matthew Desmond and Tracey Shollenberger, "Forced Displacement From Rental Housing: Prevalence and Neighborhood Consequences," Demography 52, no. 5 (October 1, 2015): 1751-72, https://doi.org/10.1007/s13524-015-0419-9.

52 Matthew Desmond and Rachel Tolbert Kimbro, "Eviction's Fallout: Housing, Hardship, and Health," Social Forces 94, no. 1 (September 1, 2015): 295-324, https://doi.org/10.1093/sf/sov044.

53 Gretchen W. Arnold, "From Victim to Offender: How Nuisance Property Laws Affect Battered Women," Journal of Interpersonal Violence, May 4, 2016, 0886260516647512, https://doi.org/10.1177/0886260516647512; Desmond and Kimbro, "Eviction's Fallout."

54 Desmond, Evicted; Matthew Desmond and Carl Gershenson, "Housing and Employment Insecurity among the Working Poor," Social Problems 63, no. 1 (February 1, 2016): 46-67, https://doi.org/10.1093/socpro/spv025.

55 Robin L. Ersing, Richard Sutphen, and Diane Nicole Loeffler, "Exploring the Impact and Implications of Residential Mobility: From the Neighborhood to the School," Advances in Social Work 10, no. 1 (March 19, 2009): 1-18.

56 Desmond and Kimbro, "Eviction's Fallout."

${ }^{57}$ Kenneth Temkin and William M. Rohe, "Social Capital and Neighborhood Stability: An Empirical Investigation," Housing Policy Debate 9, no. 1 (January 1, 1998): 61-88, https://doi.org/10.1080/10511482.1998.9521286.

58 Lyndsay N. Boggess and John R. Hipp, "Violent Crime, Residential Instability and Mobility: Does the Relationship Differ in Minority Neighborhoods?," Journal of Quantitative Criminology 26, no. 3 (September 1, 2010): 351-70, https://doi.org/10.1007/s10940-010-9093-7; Véronique Dupéré et al., "Affiliation to Youth Gangs During Adolescence: The Interaction Between Childhood Psychopathic Tendencies and Neighborhood Disadvantage," Journal of Abnormal Child Psychology 35, no. 6 (December 1, 2007): 1035-45, https://doi.org/10.1007/s10802-007-9153-0; Jeffrey D. Morenoff and Robert J. Sampson, "Violent Crime and The Spatial Dynamics of Neighborhood Transition: Chicago, 1970-1990," Social Forces 76, no. 1 (September 1, 1997): 31-64, https://doi.org/10.1093/sf/76.1.31.

${ }^{59}$ Amy J. Schulz et al., "Do Neighborhood Economic Characteristics, Racial Composition, and Residential Stability Predict Perceptions of Stress Associated with the Physical and Social Environment? Findings from a Multilevel Analysis in Detroit," Journal of Urban Health 85, no. 5 (September 1, 2008): 642-61, https://doi.org/10.1007/s11524-008-9288-5.

60 Desmond and Kimbro, "Eviction's Fallout"; Flora I. Matheson et al., "Urban Neighborhoods, Chronic Stress, Gender and Depression," Social Science \& Medicine 63, no. 10 (November 1, 2006): 2604-16, https://doi.org/10.1016/j.socscimed.2006.07.001.

${ }^{61}$ Ralph B. Taylor, "Neighborhood Responses to Disorder and Local Attachments: The Systemic Model of Attachment, Social Disorganization, and Neighborhood Use Value," Sociological Forum 11, no. 1 (March 1, 1996): 41-74, https://doi.org/10.1007/BF02408301.
} 


\section{Domestic Violence}

One of the most common-and most commonly criticized-applications of CANOs are to incidents of domestic violence. Throughout the country, cities include domestic violence as a nuisance offense; in fact, about half of the cities in Ohio with criminal activity nuisance laws include domestic violence as a nuisance offense. ${ }^{62}$ In recent months, prompted by Cleveland State University students Calla Bonnano, Vanessa Hemminger, and Marissa Pappas, several cities in Cuyahoga County (including Euclid and Parma) have amended their CANOs to remove domestic violence as a nuisance. ${ }^{63}$

In our sampled cities, between 20 and 58 percent of properties designated as a nuisance were scenes of intimate partner or familial violence. (Note that Euclid and Parma amended their law after the period of our sample.) The aggressive enforcement against domestic violence is consistent with findings of researchers in other cities, who found domestic violence is often one of the most common causes of nuisance letters, ranging from 38-48 percent of cases in Binghamton and Fulton, New York, ${ }^{64}$ to one-third of

\section{Percentage of CANO Designations for} Domestic Violence and Drug Overdose

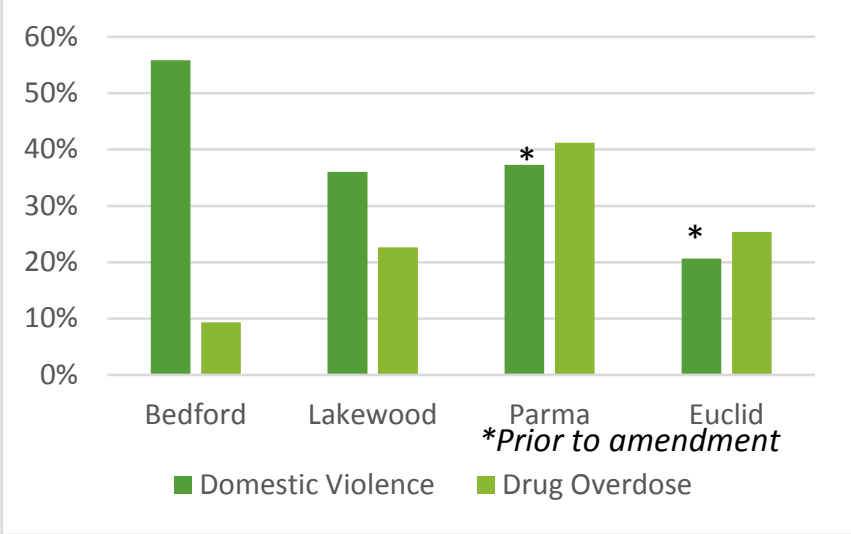
letters in Milwaukee, WI. ${ }^{65}$ As an extreme example, in Fairlawn, Ohio, almost every nuisance letter in the sampled period was sent to the scene of domestic violence. ${ }^{66}$

Here are a few examples of nuisance letters sent in response to incidents of domestic violence in cities in Northeast Ohio:

- A tenant in Lakewood ran to a neighbor's house, "bleeding from [her] face" following an attack by her boyfriend. The neighbor called 911, and police arrested the boyfriend and charged him with felonious assault and domestic violence. The police transported the tenant to the emergency room, where doctors confirmed she sustained "an apparent nasal fracture, concussion, and facial contusions." Three days later, the Lakewood law department wrote the landlord: "your tenant [] had a visitor [] over to the residence where he assaulted her. He was charged with Felonious Assault. This activity qualifies the property as a nuisance." 67

\footnotetext{
62 See Appendix A.

63 Megan E. Hatch and Joseph Mead, "Learning from Laboratory Mistakes: How Policy Entrepreneurs Catalyze City Ordinance Repeals" (Cleveland, OH, October 2017).

${ }^{64}$ American Civil Liberties Union, "Silenced: How Nuisance Ordinances Punish Crime Victims in New York."

65 Desmond and Valdez, "Unpolicing the Urban Poor."

66 Period ran from CANO enactment in 2015 to November 2016.

67 https://www.dropbox.com/s/8jb1dy8c8ngk1 kz/LL.pdf?dl=0
} 
- Bedford informed a landlord that their tenant created a nuisance one week after her partner attacked her. Police had arrived on the scene after "a 911 call from a male stating that his dad was hitting his mom." The partner was placed into custody, and the woman was transported to the hospital. Nearly a year later, Bedford fined the property owner after another domestic violence incident occurred on the property. ${ }^{68}$

- Euclid Police dispatch log reports a call from a neighbor "to state the male is beating up a female inside that apt." The incident was coded as "boy/girl trouble." The male visited, harassed, and attacked the female tenant several times over the following months. In one incident, the tenant ran to a neighbor's door, bleeding, and asked him to call the police. Shortly after, the City Law Department sent the landlord a letter, explaining the property was a nuisance because the tenant "is involved in a pattern of behavior that is disruptive to her neighbors and places an undue burden on the resources of the Euclid Police Department." The letter implies the tenant is to blame, stating "it was determined that [the tenant] willingly let [the perpetrator] into the apartment." 69

- In 2016, a Parma tenant was evicted shortly after the City sent a nuisance letter complaining about police responding to an incident of domestic violence at the property. $^{70}$

These are just a few of many examples found in these cities. CANOs present survivors of domestic violence with the impossible choice between seeking help from law enforcement and keeping their home. ${ }^{71}$ In one illustrative case from Norristown, Pennsylvania, a woman was repeatedly attacked by an ex-boyfriend, and law enforcement told her she had used up her "strikes" and future calls would be punished by the city under their CANO. Her abuser was aware that she was unable to call the police, taunting her and eventually severely attacking her to the point that she had to be rushed to the hospital. ${ }^{72}$ The city responded to the hospital trip by forcing eviction proceedings. The American Civil Liberties Union agreed to represent the woman, and she ultimately obtained a favorable settlement from the city. ${ }^{73}$

Advocates have noted-and courts have concluded-that penalizing survivors of violence is not only unjust, but likely violates the First Amendment, the Violence Against Women Act, and, by penalizing victims of a crime that is highly

CANOs give victims the impossible choice between seeking help from law enforcement and keeping their homes gendered, has a disparate impact on women in violation of the Fair Housing Act. ${ }^{74}$ In fact, last

68 https://www.dropbox.com/s/imlkgzhw69d5hh5/A.pdf?dl=0

69 https://www.dropbox.com/s/01kisa4g01vn2s6/mm.pdf?dl=0

70 https://www.dropbox.com/s/qtd1djdzoipgkea/D.pdf?dl=0

${ }^{71}$ Arnold, "From Victim to Offender"; Gretchen Arnold and Megan Slusser, "Silencing Women's Voices: Nuisance Property Laws and Battered Women," Law \& Social Inquiry 40, no. 4 (September 1, 2015): 908-36, https://doi.org/10.1111/Isi.12123.

72 https://www.theguardian.com/commentisfree/2015/sep/11/domestic-violence-victim-town-wanted-me-evicted-calling-911

73 https://www.aclu.org/cases/briggs-v-borough-norristown-et-al

74 E.g., Village of Groton v. Pirro, Case No. 523504 (N.Y. App. Div. June 15, 2017) (nuisance ordinance violated First Amendment right to petition the government), available at https://www.aclu.org/legal-document/groton-v-pirro-appellate-decision; Cari Fais, "Denying Access to Justice: The Cost of Applying Chronic Nuisance Laws to Domestic Violence," Columbia Law Review 108 
year both the United States Department of Justice and Department of Housing and Urban Development issued guidance reminding cities of their obligations under federal law. ${ }^{75}$ In many states, CANOs also conflict with state laws designed to protect survivors of domestic violence. ${ }^{76}$ Although Euclid, Parma, and several other cities agreed to amend their CANOs in an effort to stop penalizing survivors, many other cities have so far refused to act. ${ }^{77}$

\section{Criminal Activity Nuisance Ordinances with Domestic Violence in Cuyahoga County (as of August 2017)}

Domestic violence offenses are included as being a public nuisance

Domestic violence not included in public nuisance ordinance

Had a domestic violence component of nuisance law that was repealed since 2016

No public nuisance ordinance

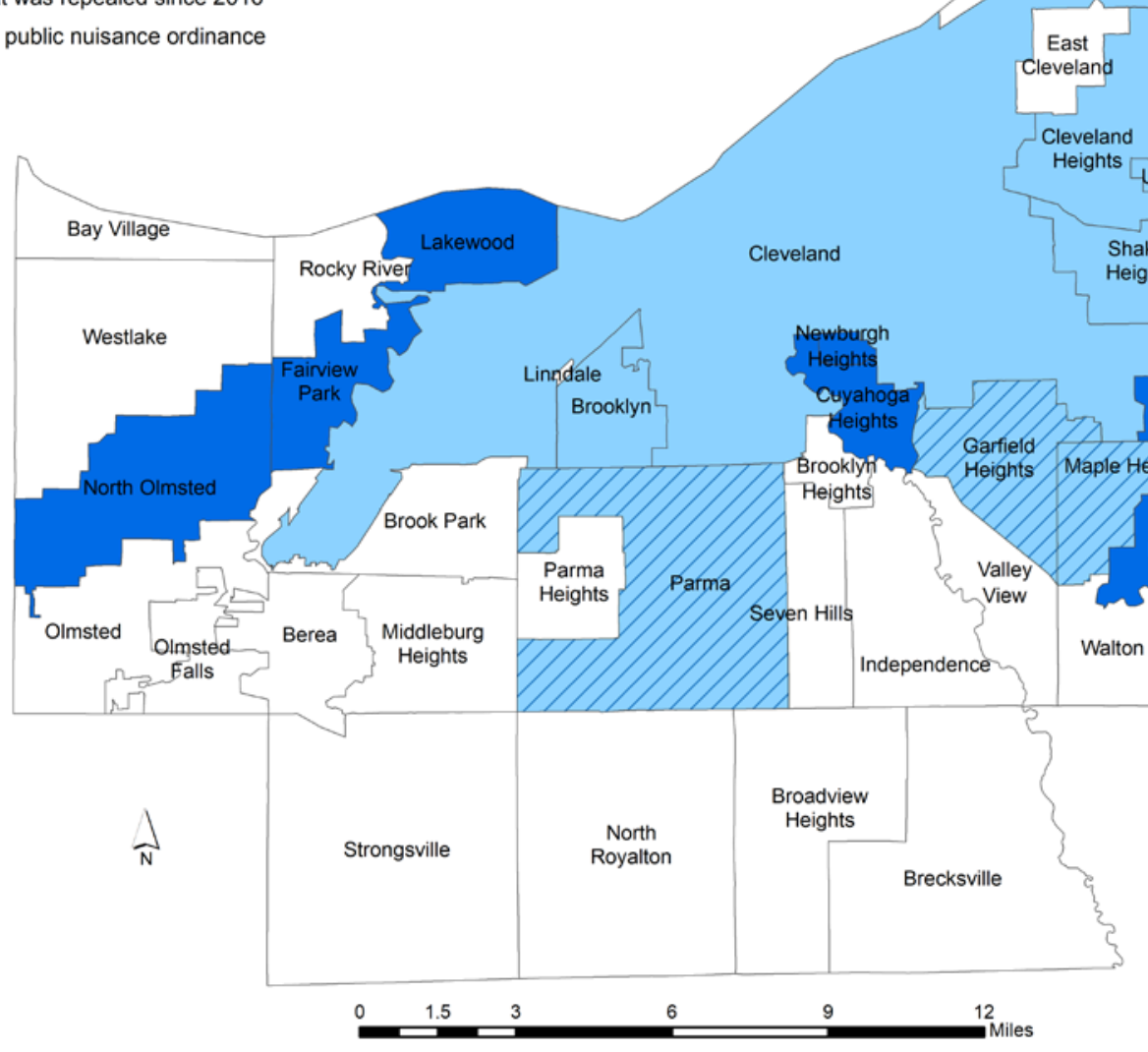

(2008): 1118-1225; Amanda K. Gavin, “Chronic Nuisance Ordinances: Turning Victim of Domestic Violence into 'Nuisances' in the Eyes of Municipalities," Penn State Law Review 119 (2014): 257-78; Filomena Gehart, "Domestic Violence Victims a Nuisance to Cities," Pepperdine Law Review 43 (2016): 1101-36; Anna Kastner, "The Other War at Home: Chronic Nuisance Laws and the Revictimization of Survivors of Domestic Violence," California Law Review 103 (2015): 1047.

75 HUD, Office of General Counsel Guidance on Application of Fair Housing Act Standards to the Enforcement of Local Nuisance and Crime-Free Housing Ordinances Against Victims of Domestic Violence, Other Crime Victims, and Others Who Require Police or Emergency Service, http://portal.hud.gov/hudportal/documents/huddoc?id=FinalNuisanceOrdGdnce.pdf;

${ }^{76}$ ACLU Amicus Brief, Village of Groton v. Pirro, Case No. 523504 (N.Y. App. Div.), available at https://www.aclu.org/groton-vpirro-aclu-amicus-brief

77 Recording of Bedford Work Session, Sept 5, 2017, https://www.dropbox.com/s/s2xpntshy9ts3ki/Recording\%20\%28excerpt\%29\%20of\%20Bedford\%20Work\%20Session\%209.5.17 MP3? $\mathrm{dl}=0$. 


\section{Mental Health Crises and Group Homes for People with Disabilities}

Cities sometimes use their CANO against individuals seeking help for a mental health crisis or medical emergency:

- A resident called a mobile crisis center and threatened to harm himself. The center notified the police, which prompted the City to send details of the call to the landlord with the warning that "[t]his activity qualifies the property as a nuisance." The letter notes that the resident previously was the victim of a pepper spray attack by an unknown assailant, and had an argument with a friend. ${ }^{78}$ The landlord initiated eviction proceedings a few weeks later.

- In an unrelated incident, a city designated a property as a nuisance in part because of the resident's "mental health issues," directing the landlord to take steps to prevent additional calls involving that tenant. ${ }^{79}$

- Earlier this year, a city fined a property owner $\$ 250$ because the tenant called the police out of concern that her boyfriend was suicidal. ${ }^{80}$ The city designated the property as a nuisance a few months earlier after the resident had previously

\section{Concern for a loved one's} mental health may cost you your home sought help for her boyfriend after he threatened to kill himself. The landlord then began uncontested eviction proceedings against the tenant.

- One city designated a property as a nuisance citing several acts of non-criminal activity, including: 1) the resident's "psychiatric situation" where the resident had "slit her wrists," 2) a "personal welfare check," conducted at a friend's request, on the resident who has not been able to afford her medications, and 3) the resident's distress over being called "crazy" and her failure to take her medication in several days. ${ }^{81}$

- Another property in was designated a nuisance based on repeated calls for a "psychiatric situation" involving a child who apparently has a mental disability (in addition to unrelated situations of domestic violence). ${ }^{82}$

In addition to designating individual homes as nuisances, cities have sometimes threatened to fine organizations that provide community-based residences for people with disabilities when their residents have a medical emergency. Community integration for people with disabilities has been a legal mandate and a clinical best practice for decades. ${ }^{83}$ However, communities are sometimes reluctant to welcome group homes into their communities. ${ }^{84}$ For example, cities

\footnotetext{
78 https://www.dropbox.com/s/xerkm3wicr6c7s5/L.pdf?dl=0

79 https://www.dropbox.com/s/2bp0g7meabmd9dt/l.pdf?dl=0

80 https://www.dropbox.com/s/krwhcmatgko111i/H.pdf?dl=0

81 https://www.dropbox.com/s/r75wkxjlv11g46n/M.pdf?dl=0

82 https://www.dropbox.com/s/fbg9oul1ud4haji/E.pdf?dl=0

83 E.g., 20 U.S.C. § 1412(a)(1), (5); Olmstead v. L.C. ex rel. Zimring, 527 U.S. 581 (1999)

${ }^{84}$ See Housing Center, State of Fair Housing in Northeast Ohio 2017, http://www.thehousingcenter.org/wpcontent/uploads/2017/04/SOFH-2017-Final.pdf.
} 
have fined group homes after staff seek assistance responding to their residents' medical emergencies:

- In Bedford, staff of a group home for children with disabilities called for assistance when a child "hit his head [and] got his eve split open and is bleeding." ${ }^{85}$ The child had to be transported to the Bedford Medical Center. The City fined the group home \$250 and threatened to criminally prosecute the property owners and charge them escalating fines if future medical assistance was required.

- At a work session held in September 2017, the Bedford City Council discussed using the CANO against the group home's affiliated school as well as part of a strategy to persuade the school to pay for an off-duty city police officer. ${ }^{86}$ Based on earlier struggles with the city, the group home filed a federal civil rights action against the City of Bedford, alleging disability discrimination. ${ }^{87}$

- Lakewood similarly threatened a group home for adults with disabilities after the staff sought police assistance after a resident attempted to harm himself and a resident went missing. ${ }^{88}$

The practice of penalizing property owners because their residents call for help for mental health crises raises issues under federal and state laws that prohibit discrimination against people with disabilities, including the Fair Housing Act and the Americans with Disabilities Act. ${ }^{89}$ For example, a fair housing organization recently sued the city of Maplewood, Missouri, for disability discrimination after it sent nuisance letters in reaction to tenants in a mental health crisis who sought medical assistance. ${ }^{90}$

Penalizing residents if they require or reach out for mental health services could discourage people from accessing the medical help that they need. Additionally, disrupting housing has

Penalizing calls for help for mental health crises may violate laws prohibiting discrimination against people with disabilities been found to worsen outcomes for people with mental health conditions. ${ }^{91}$

85 https://www.dropbox.com/s/cgj4r5b19d4hgp6/G.pdf?dl=0

${ }^{86}$ Recording of Bedford City Council Work Session, Sept 5, 2017,

https://www.dropbox.com/s/s2xpntshy9ts3ki/Recording\%20\%28excerpt\%29\%20of\%20Bedford\%20Work\%20Session\%209.5.17 MP3?dl=0 In fact, the City has gone through with its threat, and sent a bill to the alternative high school. https://www.dropbox.com/s/gyrm8h88yymskvk/EA\%20Valley\%20View 20170929 152004.pdf?dl=0

87 REACH v. Bedford, 1:15-cv-02351 (N.D. Ohio)

88 https://www.dropbox.com/s/curstruysq7f3i4/K.pdf?dl=0l

89 E.g., Laflamme v. New Horizons, Inc., 605 F.Supp.2d 378, 391 (D. Conn. 2009).

90 http://www.stltoday.com/news/local/crime-and-courts/suit-maplewood-targets-african-americans-women-disabled-withnuisance-ordinance/article d2309e7c-8822-57ea-90a5-cf3d8098b45f.html

${ }^{91}$ Yerko Rojas and Sten-Åke Stenberg, "Evictions and Suicide: A Follow-up Study of Almost 22000 Swedish Households in the Wake of the Global Financial Crisis," J Epidemiol Community Health 70, no. 4 (April 1, 2016): 409-13, https://doi.org/10.1136/jech-2015-206419. 


\section{Addiction and Drug Overdoses}

Across the cities in our sample, between 10 and $40 \%$ of applications of CANOs are related to a person experiencing a drug overdose. Many of the CANOs we reviewed explicitly include violations of criminal drug abuse laws as nuisances. ${ }^{92}$ Because of the nature of CANOs-they trigger as the result of someone calling the police-drug use applications generally relate to an overdose. In these cases, a family member, friend, or passerby finds someone needing emergency medical assistance for an overdose crisis. After the person calls for help, police or emergency response triggers the nuisance proceedings.

The City of Lakewood contains relevant examples of this phenomenon, which are representative of the cities in our sample.

- In October of 2015, a woman called 911 after she found someone had died of a drug overdose in her home. ${ }^{93} \mathrm{~A}$ few months later, she called the police again because someone else was experiencing an overdose. On that occasion, police and EMS responded and provided Narcan to the person in crisis, reviving him. A few weeks later the city sent the woman's landlord a letter informing her that emergency responses to the home qualified the property as a nuisance. The landlord initiated eviction proceedings against her tenant on the same day.

- A young man overdosed on heroin twice in his apartment within the span of a few weeks. ${ }^{94}$ Both times, someone called 911 for help and emergency responders revived the man and took him to the hospital. The city prosecutor filed criminal charges against the man, and he was sentenced to one year of probation that required he enter treatment related to substance abuse disorder. In February, the city also sent the man's landlord a nuisance letter, ordering the landlord to abate the nuisance or pay a $\$ 560$ fine. The landlord initiated eviction proceedings against the man immediately.

- A man came home from work to discover his friend, who stayed the night at his home, had died of a drug overdose. According to police reports, the man believed his friend, who suffered from addiction in the past, had stopped using drugs. A few days after his friend's death, the man became inebriated, fell out of his chair and hit his head. After police responded to help him, the city sent him a nuisance letter ordering that he pay $\$ 681$ to offset the police response. ${ }^{95}$

The medical community recognizes drug and alcohol addiction as preventable diseases. ${ }^{96}$ Drug use and addiction are closely linked with housing instability and homelessness. ${ }^{97}$ Imposing

\footnotetext{
92 E.g., Bedford Ord. 511.12(a)(2); Lakewood Ord. 501.01(a)(3). Indeed, some cities single out certain drug offenses for uniquely harsh treatment by cities that impose a "one strike" policy for drug offenses only.

93 https://www.dropbox.com/s/kyqnfgtv0madyu7/V.pdf?dl=0

94 https://www.dropbox.com/s/2sg1eyatncpp20c/U.pdf?dl=0

95 https://www.dropbox.com/s/pg5aug6cgre2jje/Z.pdf?dl=0

${ }_{96}^{6}$ See National Council for Behavioral Health, "Substance Use, Misuse, and Addiction Prevention," (2017) available at

https://www.thenationalcouncil.org/wp-content/uploads/2017/05/Prevention-Paper-FINAL.pdf

97 See, e.g., National Coalition for the Homeless, "Substance Abuse and Homelessness," (2009) available at 
criminal and other penalties on those living with addiction can act as a barrier to prevention and treatment. ${ }^{98}$ As in the second example above, CANOs can amplify these barriers by threatening someone's housing while they are also dealing with criminal proceedings.

At the state level, especially as opioid use and related deaths increase in Ohio, ${ }^{99}$ we have seen increased attempts to criminally punish drug use. ${ }^{100}$ Using local criminal laws, including CANOs, to penalize those experiencing or witnessing an overdose discourages residents from calling 911 in the event of an overdose emergency. ${ }^{101}$

Ohio enacted a Good Samaritan statute, which provides some limited immunity from criminal charges to those who call 911 to report an overdose. ${ }^{102}$ The spirit of laws like this recognizes the dangers of discouraging individuals from calling the police in an emergency situation. ${ }^{103}$ Ohio's statute, though, operates only in the criminal context, and does not directly impact the application of CANOs. The Americans with Disabilities Act and Fair Housing Act both protect people with past drug and alcohol addiction as a mental health disability, but these federal laws explicitly exclude individuals suffering from current drug or alcohol addiction, ${ }^{104}$ leaving those with drug use issues vulnerable to penalties waged by CANOs.

\section{CONCLUSION}

Criminal Activity Nuisance Ordinances are local laws that penalize residents if emergency services respond to (or near) their home multiple times. With CANOs in more than 2,000 cities nationwide-including nearly 50 in Ohio, and more than 20 in Cuyahoga County-it is important to understand the true implications of these laws in action.

\footnotetext{
98 Human Rights Watch and the American Civil Liberties Union, Every 25 Seconds: The Human Toll of Criminalizing Drug Use in the United States, at 167-169 (October 2016) available at https://www.aclu.org/report/every-25-seconds-human-toll- 
We find CANOs disproportionately target and impact residents of color, renters, and residents using housing vouchers. Analysis of thousands of pages of nuisance-related public records in our sample cities revealed a concerning trend: nuisance designations are frequently applied to the homes of survivors of domestic violence, people experiencing a mental health crisis, or residents seeking emergency medical response for a drug overdose or other substance use crisis. In the four cities for which we have complete records, more than half of nuisance letters regarded renters. In one city, 90 percent of the letters were regarding a rental property. Domestic violence was one of the most common triggers, and cities sent between 21 and 56 percent of CANO letters because of domestic violence. Responses to mental health crises and medical emergencies arising from substance abuse were also common causes of CANO letters. The legality of CANOs is called into question by the Fair Housing Act, the Violence Against Women Act, the Americans with Disabilities Act, and the U.S. Constitution.

Despite their name, cities use criminal activity nuisance ordinances to penalize behavior even when the police would be unable to sustain formal criminal charges (due to lack of evidence), or when the behavior is not in fact criminal (such as a psychiatric crisis). Forcing property owners into the regulation of resident behavior, CANOs ultimately encourage a great number of evictions. These laws may contribute to, and intensify, the prevalence of housing instability, particularly among residents already experiencing the trauma of domestic violence or psychiatric crisis. Faced with the threat of fines, eviction, or other penalties, residents may avoid reaching out to police for assistance in times of crisis-an action which can carry grave consequences.

While there are no easy solutions for the complex social issues cities are trying to address with CANOs, this report reveals a pattern of negative consequences associated with these laws that should be carefully considered by policymakers and community leaders. 
Appendix A. List of Cities and Villages in Ohio with CANOs

Cities with CANOs

\begin{tabular}{|c|c|c|c|c|}
\hline City & County & Citation & $\begin{array}{l}\text { Includes } \\
\text { Domestic } \\
\text { Violence? }\end{array}$ & $\begin{array}{l}\text { Year } \\
\text { Adopted }\end{array}$ \\
\hline Ashtabula & Ashtabula & 521.091 & No & 2011 \\
\hline Middletown & Butler & 1456.02 & No & 2015 \\
\hline East Liverpool & Columbiana & 507.01 & Yes & 2011 \\
\hline Bedford & Cuyahoga & 511.12 & Yes & 2005 \\
\hline Bedford Heights & Cuyahoga & 561.01 & No & 2007 \\
\hline Brooklyn & Cuyahoga & 503.01 & No & 2005 \\
\hline Cleveland & Cuyahoga & 630.01 & No & 2006 \\
\hline Cleveland Heights & Cuyahoga & 553.07 & No & 2003 \\
\hline Euclid & Cuyahoga & 529.07 & No & 2006 \\
\hline Fairview Park & Cuyahoga & 509.18 & Yes & 2004 \\
\hline Garfield Heights & Cuyahoga & 555.01 & No & 2011 \\
\hline Lakewood & Cuyahoga & 510.01 & Yes & 2004 \\
\hline Lyndhurst & Cuyahoga & 161.01 & No & 2009 \\
\hline Maple Heights & Cuyahoga & 648.19 & No & 2006 \\
\hline Mayfield Heights & Cuyahoga & 153 & No & 2017 \\
\hline North Olmsted & Cuyahoga & 561.01 & Yes & 2008 \\
\hline Parma & Cuyahoga & 606.31 & No & 2005 \\
\hline Shaker Heights & Cuyahoga & 109.01 & No & 2004 \\
\hline South Euclid & Cuyahoga & 531.09 & No & 2004 \\
\hline University Heights & Cuyahoga & 648.17 & No & 2004 \\
\hline Warrensville Heights & Cuyahoga & 550.01 & Yes & 2014 \\
\hline Sandusky & Erie & 531.16 & Yes & 2004 \\
\hline Fairborn & Greene & 561.01 & No & 2015 \\
\hline Cheviot & Hamilton & 111.3 & No & 2007 \\
\hline Cincinnati & Hamilton & $761-1-N$ & Yes & 2006 \\
\hline North College Hill & Hamilton & 507.01 & No & 2007 \\
\hline Painesville & Lake & 508.2 & No & 2008 \\
\hline Avon Lake & Lorain & 662.01 & Yes & 2015 \\
\hline Lorain & Lorain & 559.01 & No & 2013 \\
\hline Campbell & Mahoning & 509.12 & Yes & 2006 \\
\hline Struthers & Mahoning & 532.01 & Yes & 2012 \\
\hline Brunswick & Medina & 678.05 & No & 2005 \\
\hline Wadsworth & Medina & 93.7 & Yes & 2013 \\
\hline Aurora & Portage & 606.3 & No & 2010 \\
\hline Kent & Portage & 561.01 & No & 2004 \\
\hline Ravenna & Portage & 686.03 & No & 2011 \\
\hline Eaton & Preble & 504.01 & No & 2013 \\
\hline
\end{tabular}




\begin{tabular}{|l|l|l|l|l|}
\hline Chillicothe & Ross & 138.03 & No & 2014 \\
\hline Alliance & Stark & 734.01 & Yes & 2015 \\
\hline Akron & Summit & 139.03 & No & 2005 \\
\hline Barberton & Summit & 674.01 & No & 2005 \\
\hline Fairlawn & Summit & 680.01 & Yes & 2015 \\
\hline Norton & Summit & 674.01 & No & 2010 \\
\hline Niles & Trumbull & 501.14 & Yes & 2013 \\
\hline Orrville & Wayne & 521.13 & Yes & 2009 \\
\hline
\end{tabular}

Non-Exhaustive List of Villages with CANOs

\begin{tabular}{llllll} 
Village & County & Citation & $\begin{array}{l}\text { Includes } \\
\text { Domestic } \\
\text { Violence? }\end{array}$ & $\begin{array}{l}\text { Year } \\
\text { Adopted }\end{array}$ \\
\hline Cuyahoga Heights & Cuyahoga & 680.07 & Yes & 2012 \\
\hline Gevena-on-the-Lake & Geneva & 151.01 & Yes & 2012 \\
\hline Newburgh Heights & Cuyahoga & 1355.01 & Yes & 2007 \\
\hline Woodmere & Cuyahoga & 551.07 & Yes & 2014 \\
\hline
\end{tabular}




\section{Appendix B. Methodology}

To develop our list of cities with CANOs, we reviewed the codified laws of every city in Ohio. Because there is sometimes a delay between an ordinance's adoption and its codification, it is possible that we missed a recent CANO enactment or amendment. A small number of cities do not provide electronic or public access to their ordinances, and were not included in the sample. We compared our list of cities with lists compiled by the Housing Research and Advocacy Center and the American Civil Liberties Union of Ohio.

Through public record requests, we obtained city council minutes, audio or video recordings, and other records documenting the adoption of the CANOs in about half of the cities. The quality and completeness of the records varied widely from city to city.

For a smaller sample of cities, we also requested nuisance letters and related police reports. We chose to focus on the nuisance letters sent by four cities in Cuyahoga County-Bedford, Euclid, Lakewood, and Parma. To make claims about percentages, each letter was coded independently by two trained coders with the results compared to one another. A third coder reconciled the discrepancies. Because the cities we focused on are relatively large and active, they are not necessarily representative of smaller cities with CANOs, and we do not suggest that all cities will use their CANO in precisely the same way.

\begin{tabular}{l|l|l} 
City & Time Period & $\mathbf{n}$ \\
\hline Bedford & 1/2016 to $7 / 2017$ & 47 \\
\hline Lakewood & 2/2014 to 5/2016 & 75 \\
\hline Euclid & 10/2013 to $7 / 2016$ & 63 \\
\hline Parma & 3/2014 to $10 / 2016$ & 51 \\
\hline
\end{tabular}




\section{About the Authors}

Kristi Andrasik is pursuing a PhD in urban policy at Cleveland State University. A licensed independent social worker with a background in community-based services, she is focusing her research on issues of social equity at the intersection of lived experience, service delivery, philanthropy, and public policy.

Elizabeth Bonham is a staff attorney for the American Civil Liberties Union of Ohio, where she works to protect Ohioans from discrimination and unconstitutional government action. She received her law degree from Cleveland-Marshall College of Law.

Megan E. Hatch is an Assistant Professor of urban policy and city management at Cleveland State University. Her research focuses on the causes and consequences of policies that disproportionately affect vulnerable populations.

Joseph Mead is an Assistant Professor at Cleveland State University, where he holds a joint appointment in the Maxine Goodman Levin College of Urban Affairs and the Cleveland-Marshall College of Law. His research interests include law, poverty, and homelessness.

Marissa Pappas is an MPA candidate at Cleveland State University. She has worked with several cities to amend their nuisance ordinances to protect survivors of domestic violence. She currently serves as a board fellow with the Housing Research and Advocacy Center, and previously served as a board fellow for the ACLU of Ohio.

J. Rosie Tighe is an Associate Professor in the department of Urban Studies in the Levin College of Urban Affairs. Her research focuses on housing policy, race and ethnicity, and neighborhood revitalization. 